\section{B A Institute of \\ YK Business Administration \\ तर Karachi \\ Leadership and Ideas for Tomorrow}

Article 8

Volume 4 Issue 2 July-December 2009

$1-7-2009$

\title{
Dutch disease in Pakistan
}

Muhammad T. Khalid

Lahore University of Management Sciences, Lahore, Pakistan

Follow this and additional works at: https://ir.iba.edu.pk/businessreview

Part of the Immunology and Infectious Disease Commons

c) (i)

This work is licensed under a Creative Commons Attribution 4.0 International License.

\section{Recommended Citation}

Khalid, M. T. (2009). Dutch disease in Pakistan. Business Review, 4(2), 97-106. Retrieved from https://doi.org/10.54784/1990-6587.1334

This article is brought to you by iRepository for open access under the Creative Commons Attribution 4.0 License and is available at https://ir.iba.edu.pk/businessreview/vol4/iss2/8. For more information, please contact irepository@iba.edu.pk. 


\title{
DISCUSSION
}

\section{Dutch Disease in Pakistan}

\author{
Muhammad T. Khalid \\ Lahore University of Management Sciences, Lahore, Pakistan
}

\begin{abstract}
In recent years Pakistan has faced a rapidly growing services sector which has lead some observers to believe that there is a transfer of resources occurring in Pakistan from the tradable to the non-tradable sector, hence causing the Dutch Disease in the economy. However no precise response has been offered on this subject. This paper seeks to provide empirical evidence on the question of the existence of Dutch Disease in Pakistan by using Linda Kamas's model on Dutch Disease. The percentage change in the growth of the tradable and the non-tradable sectors in Pakistan is calculated by using data from the Economic Survey of Pakistan from the Fiscal Year (FY) 1995-1996 to the FY 2006-2007. It is found that although the non-tradable sector growth has increased by a little larger amount than the growth of the tradable sector, there is still steady increase in the tradable sector growth. Hence empirical evidence indicates that the Dutch Disease does not exist in Pakistan.
\end{abstract}

Keywords: Dutch Disease

\section{INTRODUCTION}

The services sector has been gaining considerable importance in Pakistan's economy in the recent years. Recently it has been the major growth engine of the economy contributing a significantly large chunk to the overall GDP growth. Financial and insurance services, construction services and retail \& wholesale trade are some of the major areas which depicted strong growth within the economy and underwent sizable expansion in the recent past. On the other hand, during the 1990s the manufacturing sector had been the major source of driving Pakistan's GDP growth. Both the large and the small scale manufacturing had experienced considerable positive growth. Along with this the agriculture sector had also contributed positively towards the GDP growth rate in most of the years during that period. The services sector had occupied comparatively less importance. However the scenario has rapidly been changing over the period of time and the services sector has steadily been gaining more significance. In such circumstances some observers feel that the Dutch Disease has been taking root in Pakistan in the aftermath of the changes that have been taking place after the attacks of September 11, 2001. 
Fig. (i): Annual Percent Growth in Services Sector 1996-2007

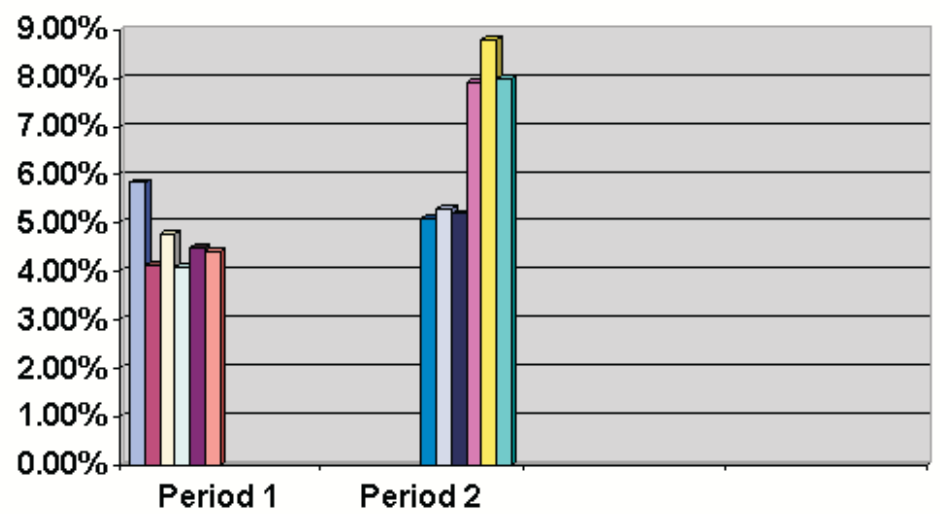

The concept of the Dutch Disease originates from what happened in the Netherlands during the 1960s. Netherlands experienced major increases in its domestic production after the discovery of huge natural-gas deposits in the 1960s. A boom in the exports of this natural resource caused an appreciation of the guilder in real terms, thus reducing the profitability of other exports, especially manufactures. Almost the entire non-oil tradable sector suffered a decline as a ripple effect of this [Sachs \& Larrain (1993)].

Although a natural-resource boom has often been the cause of the Dutch Disease, there can be other reasons for a decline in the tradable sector in the favor of the non-tradable sector. A high influx of foreign aid, foreign investment or remittances may also cause this Dutch Disease phenomenon to trigger. A fiscal expansion by the Government which is not coupled with a decline in private spending can also lead to a shift of production from tradables to non-tradables hence causing Dutch Disease [Sachs \& Larrain (1993)]. In the case of Pakistan, although there has been no natural resource boom, there has been a high degree of foreign exchange flowing into the economy in the form of remittances, foreign aid, and investment. Additionally there has also been increased fiscal spending by the Government and this was not coupled with a decline in private spending. Thus increasing growth in the services sector has given rise to the question that" is the Dutch Disease taking root in Pakistan?" 
This study seeks to investigate the hypothesis that does the Dutch Disease exist in Pakistan. This will be done by comparing in two different time periods, the growth in the commodity sector-which is the tradable sector of the country, with the growth in the services sector-which is the non-tradable sector in Pakistan. The period from the fiscal year (FY) 1996 to the FY 2001 constitutes the period I, and the period from the FY 2002 to the FY 2007 constitutes the period II. In general, while the growth in the Services sector has become more prominent than the growth of the Manufacturing sector during period II, it is detected that the Manufacturing sector's growth has not lost steam and has increased significantly compared to its value in period I. The rest of the paper is divided into four sections. Section II reviews the theory and literature that currently exists regarding the Dutch Disease. Section III gives an overview of the methodology that has been used to arrive at the results of this study. Section IV presents the results of the investigation. Finally the paper is concluded in section V.

\section{THE DUTCH DISEASE-THEORY AND LITERATURE}

The core model of the Dutch Disease Theory is found in the work of Corden and Neary (1982). In their core model, they divided the economy into three sectors-the booming export sector, the lagging export sector and the non-tradable goods sector. The booming export sector and the lagging export sector are the tradable sectors whereas services generally constitute the non-tradable sector. Corden and Neary then demonstrated that the traditional tradable sector may be crowded out by the other two sectors as a result of an appreciation of the real exchange rate (REER) of the domestic currency, because the appreciation causes the traditional exports to become less competitive in the world market and thus less attractive for importers.

Sachs and Larrain (1993) note that, a shift of production between tradables and non-tradables can occur whenever large shifts in the levels of domestic spending take place. This may happen when an economy begins to repay its debts, but there may be other reasons as well. An influx of foreign aid, foreign investment or remittances may also lead to this phenomenon. One case that has been receiving considerable attention from economists is that of a country that encounters significant change in its wealth because of changes in the value of natural resources possessed by the residents of the country. There are various examples of this occurring like the discovery of oil deposits by Norway in the North Sea, or the large increase in the incomes of oil exporting countries during the 1970s. It must be noted that in the developed countries the industrial sector mainly constitutes the traditional tradable sector, however in the Less Developed 
Countries the agricultural sector is also a major part of the tradable sector (Stijins, 2003). Additionally, Olusi and Olagunju (2005) point out that in the Less Developed Countries, labor and other resources migrate to the non-tradable sector of services and the relatively small import substituting manufacturing sector.

Although there is a considerable amount of theoretical literature available on the Dutch Disease, there is also a significant amount of empirical literature available on this phenomenon. It has been empirically demonstrated by Ellman (1981) that the exploitation of natural gas deposits in the Netherlands lead to sharp declines in the country's textile and clothing, metal manufacturing, mechanical engineering, automobile and shipping industries. Only the services sector expanded which was the non-tradable sector. However Barker (1981) and Kremers (1985) contend, that it cannot be established that the energy boom lead to this decline because some other countries in Western Europe also experienced a similar decline without having an energy boom.

Empirical evidence of Dutch Disease has also been sighted in the cases of various other countries. Ross (1986) diagnosed various symptoms of the Dutch Disease in the case of the United Kingdom. Commercial exploitation of crude oil began in 1975 in the UK. The REER in the country appreciated by around $53 \%$ between the years 1977 and 1980. This lead to a decline in UK's manufacturing output. However Forysth (1985) argues that although evidence of Dutch Disease in the UK exists, but it is not possible to precisely measure the impact of the resource boom on structural changes in the economy.

Results of the study by Jimenez-Rodriguez and Sanchez (2003) are mixed. They investigated the cases of Norway and the UK. They concluded that the oil price increases had a considerable negative impact on the GDP growth of UK, but the price increases benefited Norway. In addition to this, Brown and Yucel (1999) demonstrated that even the US economy is not immune to the Dutch Disease, although the US is not a net oil-exporter. Their model showed that an oil price shock caused a decline in their real GDP.

Another comprehensive literary survey was carried out by Stijns (2003) which used the World Trade Data rather than focusing on a particular set of countries. He concluded that booms arising due to energy-prices have systematically hurt the manufacturing exports of the energy exporters. 
It is evident that considerable evidence about the existence of the Dutch Disease in the Developed countries is present. However now we move to the cases of Dutch Disease that have been found in the Less Developed Countries. First there is the example of Indonesia, however it is a unique case because it is contended that Indonesia managed its currency wisely and did not have to undergo the effects of Dutch Disease (Olusi and Olagunju, 2005). Warr (1985) notes, that although the energy boom had a considerable impact on the domestic prices in Indonesia, it is unclear whether the structure of the economy underwent any change. Roemer (1994) also states, that the Indonesian Government avoided the most intense effects of the Dutch Disease through careful management of the exchange rate. In various other studies it has been demonstrated that a natural resource boom did not lead to the Dutch Disease. For instance in the cases of Kuwait, Indonesia and Mexico, the growth rate of the manufacturing sector was equal to or surpassed the growth rate of the non-tradable sector. However Olusi and Olagunju (2005) contend that the effects of Dutch Disease did take place in some of these countries, they occurred in the form of the declining agricultural sector rather than the manufacturing sector. Apart from this Voss (1996) contends that aid inflows have tended to generate fairly strong Dutch Disease effects for Pakistan.

In the back drop of the above quoted literature, this paper will now investigate whether the Dutch Disease effects have set-in in the case of Pakistan. We first lay down the methodology that was used to arrive at the results.

\section{METHODOLOGY}

The research conducted to investigate the hypothesis of this paper uses the replication of a model that was originally used by Linda Kamas (1986) [qtd. in Sachs \& Larrain (1993)]. to study the "Dutch Disease economics and the Columbian Export Boom," and was published by the World Bank.

Data was obtained for the growth performance of the tradable and the nontradable sectors of the economy as a percentage at constant factor cost. The average over period I and period II of the annual growth percentages in each sector was then calculated using excel-worksheets to find the annual average percent growth of production in each selected sector for period I and period II. Finally the percentage change from period I to period II in the annual average percent growth of production in each sector was calculated by subtracting the value obtained for the annual average percent growth for period I from the value obtained for period II. These values for the percentage change in growth that occurred in moving from period I to period II were then used to analyze whether there has been a shift in resources from the tradable to the non-tradable sector in Pakistan. 
The classifications made by the Economic Survey of Pakistan of the different component sectors of the Gross National Product (GNP) were used for this study. The Economic Survey of Pakistan is annually published by the Finance Division of the Government of Pakistan. The annual publications from the FY 1995-1996 to the FY 2006-2007 were used. The classifications were organized as follows. The tradable sector was taken as the commodity sector-constituted by agriculture, mining \& quarrying, and manufacturing.- and finally the electricity \& gas distribution sector. Agriculture was divided into the major crops, the minor crops, livestock, fishing, and forestry. Manufacturing was divided into the large-scale manufacturing and the small scale manufacturing, The non-tradable sector was taken as the services sector-constituted by transportation, storage $\&$ communications, wholesale \& retail trade, finance \& insurance, ownership of dwellings, public administration and defense, construction services and other services. It must be pointed out that construction services were a part of the commodity sector in older classifications, however they were included as a part of the services sector for the purpose of this study in order to follow the latest classifications which have been hailed as being more accurate. It should also be noted that the growth of exports was added to the picture to get a more holistic view of the Dutch Disease problem although theoriginal model by Linda Kamas (1986) does not take exports into account.

The empirical data for the above mentioned sectors was then obtained from the "growth and investments" section and the "external trade" section of the Economic Survey of Pakistan.

\section{RESULTS}

The results of this study are presented in Table 1 below and the bar-chart in Figure 1. Both Table 1 and Figure 1 indicate the percentage change from period I to period II in the growth rates of the commodity sector, the services sector and their components. The services sector was growing at a growth rate of $4.63 \%$ in period I and this increased to a growth rate of $6.57 \%$ in period II. Thus there was a positive change in the growth rate of $2.09 \%$ moving from period I to period II. The major increase in growth occurred in the financial and insurance services sector-which is of $6.14 \%$, followed by the construction services sector having an increase of around $4.94 \%$. Public expenditure \& defense, and wholesale \& retail trade also experienced increases in their growth rates. However transport, storage and communications, ownership of dwellings and other services experienced a decline in their growth rates. 
Table 1

THE RECOMPOSITION OF PRODUCTION IN PAKISTAN DURING, 1996-2007 (Annual Average Percent Growth Of Production In Selected Sectors)

\begin{tabular}{|c|c|c|c|}
\hline & \multicolumn{3}{|c|}{ GROWTH } \\
\hline & 1996-2001 & $2002-2007$ & $\%$ Change \\
\hline Commodity Sector & 3.65 & 5.57 & 1.92 \\
\hline Agriculture & 2.77 & 3.87 & 1.09 \\
\hline Major crops & 1.82 & 4.90 & 3.08 \\
\hline Minor crops & 2.63 & 1.48 & $(1.15)$ \\
\hline Livestock & 4.33 & 3.92 & $(0.42)$ \\
\hline Fishing & 4.07 & 5.13 & 1.06 \\
\hline Forestry & $(12.17)$ & $(0.03)$ & 12.14 \\
\hline Mining and Quarrying & 2.08 & 4.62 & 2.54 \\
\hline Manufacturing & 4.49 & 9.18 & 4.69 \\
\hline Large Scale & 3.07 & 10.50 & 7.44 \\
\hline Small Scale & 7.37 & 6.90 & $(0.47)$ \\
\hline Electricity \& Gas Distribution & 6.94 & $(0.95)$ & $(7.89)$ \\
\hline Services Sector & 4.63 & 6.72 & 2.09 \\
\hline Transport, Storage \& Communications & 5.20 & 4.28 & $(0.91)$ \\
\hline Wholesale \& Retail Trade & 3.58 & 7.75 & 4.17 \\
\hline Finance \& Insurance & 4.15 & 10.28 & 6.14 \\
\hline Ownership of Dwellings & 5.29 & 4.10 & $(1.19)$ \\
\hline Public Admin and Defence & 3.37 & 6.67 & 3.30 \\
\hline Construction & 2.53 & 7.47 & 4.94 \\
\hline Other Services & 6.52 & 6.37 & $(0.15)$ \\
\hline Commodity Exports & 2.32 & 11.5 & 9.18 \\
\hline
\end{tabular}




\section{Figure 1}

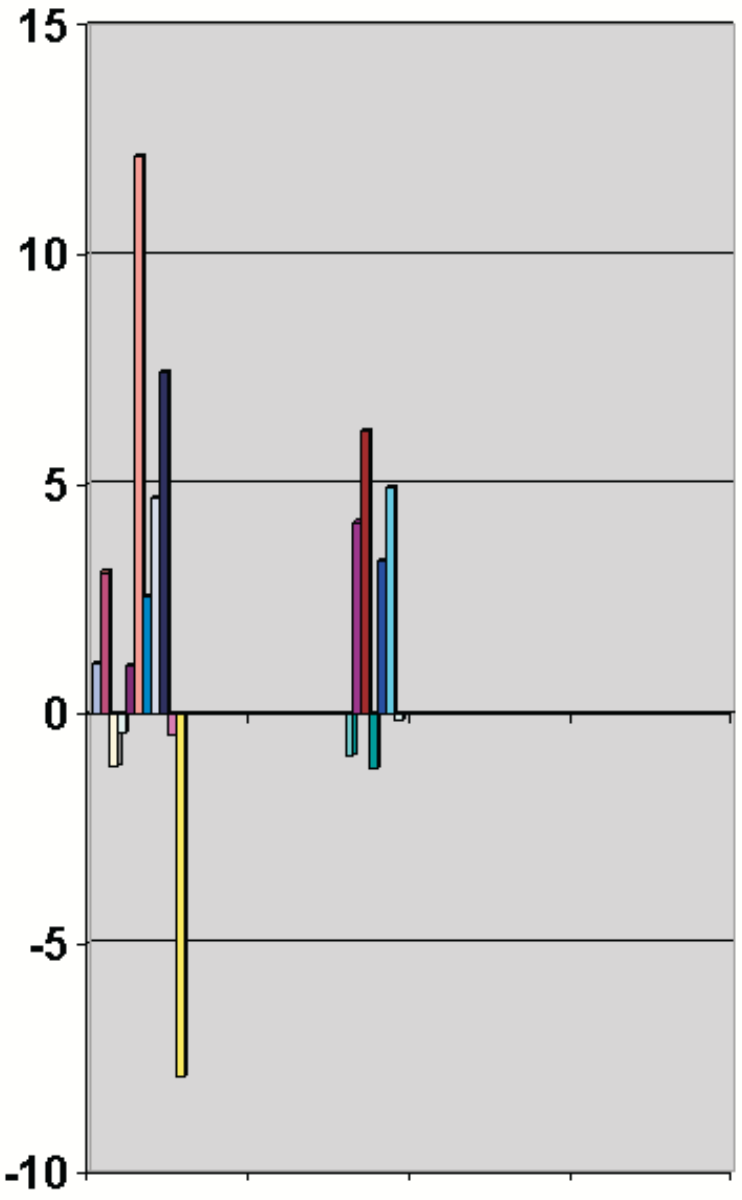

$\square$ Agriculture

$\square$ Major Crops

Minor Crops

$\square$ Livestock

$\square$ Fishing

$\square$ Forestry

$\square$ Mining and Quarrying

$\square$ Manufacturing

$\square$ Large Scale

$\square$ Small Scale

$\square$ Electricity \& Gas Distribution

$\square$ Transport, Storage \& Communication

$\square$ Wholesale \& Retail Trade

Finance \& Insurance

$\square$ Ownership of Dwellings

Public Admn. \& Defence

$\square$ Construction

$\square$ Other Services 
While the services sector experienced an increase in growth of $2.09 \%$, the commodity sector moving from period I to period II had a percentage increase in its growth of $1.92 \%$. The commodity sector growth had been $3.65 \%$ in period I, which increased to $5.57 \%$ in period II. Major crops, large scale manufacturing, forestry, fishing, and mining \& quarrying all experienced an increase in their growth. However minor crops, small-scale manufacturing, electricity \& gas distribution and livestock experienced a decline in growth.

These results indicate that growth in both the services and the commodity sector has increased. The increase in the growth of services is a bit higher than the increase in the growth of the commodity sector (some charts in the appendix), however it is stressed that the commodity sector growth has not failed to rise. It has shown a steady increase $(1.92 \%)$ which is just a little $(0.17 \%)$ less than that of service $(2.09 \%)$. Hence, there is no evidence of a transfer of resources from the tradable to the nontradable sector, and thus it shows that the Dutch Disease does not exist in Pakistan.

Apart from the Growth in the commodity and the services sector, growth in Pakistan's commodity-exports has experienced an increase of around 9.2\%. It was around $2.31 \%$ during period I but increased to around $11.5 \%$ in period II.

\section{CONCLUSION}

This study shows that there is no concrete evidence of the existence of the Dutch Disease in Pakistan. Although the non-tradables experienced a greater increase in growth than the tradables, and the overall magnitude of their growth was greater than that of the tradables in period II, there has still been an increase in the growth of the tradable sector of $1.92 \%$. This means that the tradable sector is steadily growing at an increasing rate. It is acknowledged that some sectors on the commodity side like minor crops and small-scale manufacturing have experienced reduced growth, but the magnitude of the decline in these sectors is quite small. There is no major shift in the resources from the tradable to the non-tradable sector. This observation is further supported by the fact that there has been a sizeable increase in the commodity-exports of Pakistan whereas Dutch Disease is signified by a fall in traditional commodity exports.

Hence it is concluded that although the services sector has gained more importance over time in Pakistan, empirical evidence indicates that the Dutch Disease does not exists in the country's economy. 


\section{REFERENCES}

Barker, T. (1981) Policy Issues in Energy-rich Economies. In T. Barker and V. Brailovsky (eds.) Oil or Industry. London: Academic Press.

Brown, S.P.D., and M. K. Yucel (1999) Oil Prices and US Aggregate Economic Activity: A Question of Neutrality. Economic and Financial Review. Federal Research Bank of Dallas. Corden, W., and J. Neary (1982) Booming Sector and De-industrialisation in a Small Open Economy. Economic Journal 92. (December), 825-848. Reprinted in W. Corden (ed.) (1992) International Trade Theory and Policy. Selected Essays of W. Max Corden, Aldershot: Elgar.

Economic Survey of Pakistan. (1996-2007). Finance Division: Ministry of Finance, Government of Pakistan.

Ellman, M. (1981) Natural Gas, Restructuring and Reindustrialisation: The Dutch Experience of Industrial Policy. In T. Barker and V. Brailovsky (eds.) Oil or Industry. London: Academic Press.

Forsyth, P. (1985) Booming Sectors and Structural Change in Australia and Britain: A Comparison. In P. Neary and S. Van Winbergen (eds.) Natural Resources and Macroeconomy. Oxford: Basil Blackwell Ltd.

Jimenez-Rodriguez, R., and M. Sanchez (2003) Oil Price Shocks and Real GDP Growth: Empirical Evidence for Some OECD Countries (Mimeographed.)

Kremers, J. (1985) Booming Sectors and Structural Change in Australia and Britain: A Comparison. In P. Neary and S. W. Van Winbergen (eds.) Natural Resources and the Macroeconomy. Oxford: Basil Blackwell Ltd.

Olusi, J., and M. Olagunju (2005) The Primary Sectors of the economy and the Dutch Disease in Nigeria. Pakistan Development Review 2005. (Summer), pp 159-175

Roemer, M. (1994) Dutch Disease and Economic Growth: The Legacy of Indonesia, Harvard Institute for International Development. (June), pp 1-14. (Development Discussion Paper No. 489.)

Sachs, J., and Larrain, F. (1993) Macroeconomics in the Global Economy. New Jersy: Prentice Hall Ehglewood Cliffs,

Stijns, J. (2003) An Empirical Test of the Dutch Disease Hypothesis Using a Gravity Model. Paper presented at the Congress of EEA, Stockholm, August, pp 20-24.

Warr, P. (1985) Indonesia's Other Dutch Disease. In P. Neary and S. V. Winbergen (eds.) Natural Resources and the Macroeconomy. Oxford: Basil Blackwell Ltd. 